\title{
Morphological Characteristics of English Football Language
}

\author{
Elgilani Khalil Osman Elfaki ${ }^{1}$ \\ ${ }^{1}$ Translation \& English Language, Majmaah University, KSA \\ Correspondence: Elgilani Khalil Osman Elfaki, Translation \& English Language, Majmaah University, KSA. \\ E-mail: gilanijazu@gmail.com
}

Received: October 20, 2021

Accepted: November 30, $2021 \quad$ Online Published: December 7, 2021

doi:10.5539/ijel.v12n1p148

URL: https://doi.org/10.5539/ijel.v12n1p148

\begin{abstract}
Football is the most popular sport globally. It is considerably modern sport, nevertheless, attracted millions zealous followers. Several media outlets cover activities and events of football world-wide around the clock. The researcher has been attracted and encouraged by follow-up and study of hundreds of native English football texts on specialized sports and football media outlets as newspapers, magazines, T.V and radio programs as well as electronic sites. At the end of the study, the researcher has analyzed these texts linguistically and then classified them according to their morphological categorizations. Football morphological elements surfaced by the researcher include affixation, compounding, clipping, eponymy, and loans (borrowings). At the end of the study, the researcher has provided some related results and recommendations.
\end{abstract}

Keywords: football, morphological characteristics, affixation, compounding, acronymy, clipping, eponymy

\section{Objectives}

The study aims to:

1) cast light on morphological characteristics of English football language.

2) contribute to linguistics field in general and morphology in particular by introducing and presenting new elements and characteristics from football language.

3) enrich morphology with new terms.

The current study tries to answer the following questions:

1) What are morphological characteristics of English football language.

2) What are sources of English football language.

3) To what extent can football language contribute to morphology.

It is hypothesized that:

1) English football language is rich in morphological elements.

2) Football linguistics can be developed together with other sports branches to be a sub-specialty of linguistics.

\section{Methodology}

The present work is a is a theoretical descriptive study based on collection of native English football language of texts from various sources of football media as newspapers, magazines, T.V and radio programs, and official sports electronic sites. The researcher for more than two years of constant follow-up and observation has carefully and accurately analyzed these texts. Therefore, analyzing any text is interesting for authors and readers, for example, legal texts by Hazem and Kanaan (2020).

\section{Morphology}

Morphology is the linguistic study of how words are formed in a language. Parker and Riley (2010, p. 79) confirm "Morphology is the study of word formation. Morphology is to words what syntax is to sentences. That is, morphology is concerned with the structure of words, just as syntax is concerned with the structure of sentences". Morphology gives an answer to how words are formed in a specific language. It is also the study of the internal structure of a word element in English football language include the following types: 


\subsection{Affixation}

In English morphology, affixation is a method of using an affix i.e., a prefix (which occurs at the beginning of words as re-, post-, self-, ir-, im-, sub-. Examples, replay, reschedule, post-modernism, post-war, self-study, self-rule, irresponsible, irregular, impassable, impatient, subcommittee, subcontinent respectively) or an infix (which occurs in the middle of a word as 'ee' in geese, feet 'e' in men, women) or a suffix (which occurs at the end of a word as -ment, -ion, -er, -or, -ship, -logy, -logist, -ism. Examples, statement, government, election, reflection, reminder, receiver, commentator, donator, professorship, kinship, psychology, histology, cardiologist, pathologist, secularism and capitalism respectively). Widdowson (1996, p. 46) states "Derivation has to do with the way morphemes get attached as affixes to existing lexical forms or stems in the process of word formation. Some affixes, for example, de-, dis-, un- and pre- are attached at the beginning (i.e., are prefixes), and some (for example, -ure, -age, -ing, -ize, -ful, and -able) are attached at the end (i.e., are suffixes)". Affixes are bound morphemes; that cannot stand by themselves unless attached to other form(s), nevertheless, they have fixed meanings. It is quite observable that majority of English words consist of affixes; these affixes of different native origins such as Latin, French and other European languages.

Nation (2013, p. 389) indicates, "Most of the content words of English can change their form by adding prefixes or suffixes".

\section{Prefixes:}

A prefix is an affix added at the beginning of a word. It is used to create new word. Yule (1996, p. 69) states "some affixes have to be added to the beginning of a word (e.g., un-). These are called prefixes".

Prefixes are widely used in English for making new words for different purposes as:

1) Negation: negation prefixes are used to introduce exact opposite items, objects, ideas, or denial of existence of something. Kamil and Hazem (2019) state "The negation process is a universal phenomenon and differs from language to another". Examples, 'non' as non-aggression, 'a' asymmetry, 'in' intolerant, 'im' immoral, 'ir' irregular, 'un' unhappy, 'il' illicit, 'un' undo, and 'dis' disown.

2) Opposition: 'anti' anti-Semitism.

3) Half: 'hemi' hemisphere, 'semi' semi-final, 'quasi' quasi-governmental.

4) Repetition: 're' recount.

Other forms of prefixes include ab-, counter-, dis-, en-, over-, pre-, under-, sub-, ... etc.

Types of commonly-used English Prefixes:

Prefixes in Football:

1) Anti-: Anti-doping, anticompetitive.

2) Arch-: Archrival.

3) Counter-: Counterattack.

4) Dis-: Disqualify, dismiss.

5) Extra-: Extra time.

6) Quarter-: Quarterfinal.

7) Pre-: Pre-match, preseason.

8) pos-t: Post match.

9) Re-: Re-match, re-play.

9) Un-: Unmarked, unbeaten.

10) Semi-: Semifinal.

\section{Suffixes}

Suffixes are endings or words parts attached to words ends to create further meanings. Stageberg (1981, p. 91) "Suffixes are bound morphemes that occur after a base. Suffixes may pile up to the number of three or four". They are extensively used in English to produce more words. Examples:

1) -ize/ise (British): for making verbs out of some nouns and adjectives as in computerize, legalize. Ballard (2001, p. 52) "Of the verb suffixes, -ise/-ize is used far more extensively to create new words than others". 
2) -en: attached at the end of certain adjectives and nouns to make verbs as weaken, broaden, tighten, widen, lengthen, and strengthen.

More suffixes include: -ess, -ness, -ful, -less, -ist, -ism, -logy, -logist, -ic, -al, .... Etc.

Suffixes in Football Language:

1) -er: winner, attacker, defender, goalkeeper, header.

2) -ee: contractee, marquee, loanee.

3) -less: goalless, scoreless, winless.

4) -ism: professionalism, hooliganism, dynamism.

5) -ist: finalist, trialist. medalist.

6) -ing: booing, scoring, sporting, footballing.

7) -ize: equalize, penalize.

8) -izer: equalizer.

\subsection{Conversion}

Conversion is shift in words function i.e., change in word class and meaning without change in the word. Yule (2010, p. 57) describes conversion as a "change in the function of a word, as for example when a noun comes to be used as a verb (without any reduction) .......... other labels for this very common process are "category change" and "functional shift". Common examples are: chair, vacation, butter and bottle.

Conversion in football language include:

1) Noun + Verb Conversion: kick, captain, foul, whistle, lineup, coach, pass, boo, draw, red card, warm up, substitute, cohost, yellow card, caution, transfer, move, debut, top, crown, tackle.

2) Adjective + Noun Conversion:

Topflight, medical, friendly, international, daily.

\subsection{Acronyms}

An acronym is a word synthesized from initial letters of different words to give a single word. O' Grady et al. (1997, p. 159) define them "Acronyms are formed by taking the initial letters of some or all of the words in a phrase or title and reading them as a word. This type of word formation is especially common in names of organizations and scientific terminology". Examples are: TOEFL: Test of English as a Foreign Language, IELTS: International English Language Testing System, PIN, Laser, and Radar. Finegan (2015, p. 50) further and clearly points out that acronyms are "shortenings in which the initial letters of the words in an expression are joined and pronounced as a word are acronyms". Thus, it is a clear-cut differentiation from initialisms, which are pronounced as single words.

Commonly-used Acronyms in English:

TOEFL: Test of English as a Foreign Language, IELTS: International English Language Testing System, PIN: Personal Identification Number, Laser: light amplification by the stimulated emission of radiation, Radar: radio detection and ranging.

Acronyms in football language include:

1) VAR: Video Assistant Referee.

2) UEFA: Union of European Football Associations.

3) CECAFA: The Council for East and Central Africa Football Associations.

4) IFAB: International Football Association Board.

5) FIFA: Federation Internationale de Football Association (loan from French).

6) CAF: Confederation of African Football.

8) CONCACAF: The Confederation of North, Central American and Caribbean Association football.

9) CAS: Court of Arbitration for Sport.

\subsection{Initialisms/Abbreviations}

Initialisms or abbreviations are a set of initial letters written and pronounced separately. Abbreviations are 
common and widely used in all sectors of English language, especially in English scientific domains.

Parker et al. (2010, p. 94) "An abbreviation is a word formed from the names of the first letters of the prominent syllables of a word (e.g., TV < television) or of words in a phrase (e.g., FBI < Federal Bureau of Investigation)". Other common examples are: UN: United Nations, CIA: Central Intelligence Agency, UK: United Kingdom, GB: Great Britain, AU: African Union.

Commonly-used Abbreviations in English are:

UN: United Nations, CIA: Central Intelligence Agency, UK: United Kingdom, GB: Great Britain, AU: African Union,

Football abbreviations include L: loss, D: draw, A: away, C: captain, FC: football club, FA: football association, Vs: versus, AF: association football, F: forward, GK: goalkeeper, DM: defensive midfielder, LB: left back, RB: right back, FB: full back, UCL: UEFA Champions League, EPL: The English Premier League, IOC: International Olympic Committee.

\subsection{Compounding}

Is two or more words linked together in order to form a single new word. Hurtford et al. (2007, p. 227) explains "A derived word formed by combing two pre-existing words in a language is called a compound word". Common examples as: blackmail, blackboard, startup, roadmap, high treason, brother-in-law, greenhouse, boy scouts, ice cream, check-in, one-half, bus stop, and software.

Franklin et al. (2011, p. 61) "Although two-words compounds are the most common in English, it would be difficult to state an upper limit". Therefore, a compound word of more than two words can be found in English. Examples, merry-go-round, sister-in-law, over-the-counter, and state-of-the-art.

Compounds in football language include: free kick, goalkeeper, linesman, halftime, football, footballer, fair play, lineup, head coach, Centre back, runner up, match-fixing, first half, second half, left footer, crossbar, football association, association football, armband, scoresheet, playmaker, touch-line, kickoff, goalpost, goal line, penalty mark, goal scorer.

\subsection{Clipping}

Clipping is cutting off or shortening a word of more than one syllable into one word. The result is one part is used as a word, whereas, the second part is discarded. Clippings in English are widely used, because English native speakers tend to clip their words to avoid and get rid of long words. Franklin et al. (2011, p. 504) assert "Is the abbreviation of longer words into shorter ones, such as fax for facsimile, the British word telly for television, prof for professor, piano for pianoforte, and gym for gymnasium. Once considered slang, these words have now become lexicalized, that is, full words in their own right". Examples of clipping in common English language are: Exam Examination, lab-laboratory, mag-magazine, celeb-celebrity, phone-telephone, fridge-refrigerator. Clipped words are usually used in informal contexts.

Clippings in football language are common and popular. They used as pet names and/or nicknames as: Ron: Ronaldo, Leo: Lionel Messi, Keeper: goalkeeper, pro: professional, gym: gymnasium, sub: substitute, ref: referee, physio: physiotherapist. Clippings in football also include proper nouns as Barca: Barcelona, City: Manchester City, United: Manchester United, Madrid: Real Madrid, The Spurs: Totten ham hotspur, Bayern: Bayern Munich, Betis: Real Betis. Yule (2010, p. 56) confirms how clippings happen in the language "This occurs when a word of more than one syllable (facsimile) is reduced to a shorter form (fax)". More supporting examples as: lib: liberal, rep.: representative, Ed: Edward, and Joe: Joseph.

\subsection{Loan Words (Borrowings)}

English is an absorptive, flexible language. It has borrowed words from most global languages. Sambrook (1947, p. 66) notices, "Almost every language spoken in the world is represented in English, and the borrowings are increasing every year". For example, English has borrowed 'tsunami' from Japanese, 'cotton' from Arabic, 'paparazzi' from Italian, 'yoghurt' from Turkish, 'faux pas' from French, 'alligator' from Spanish, 'cobra' from Portuguese, and 'frankfurter' from German. Saraceni (2015, p. 111) confirms 'Indeed, borrowing is a classic concept in sociolinguistics, which describes the process in which a 'bit' of one language is replicated in another. The 'bit' is often a word or phrase, but it can also be an element of phonology, grammar, or syntax".

Borrowings/Loan Words in Football:

They are mostly from French, Italian, Spanish, and to less extent from German. Examples, Los Blancos (The Whites 'Real Madrid Club'), Copa del Rey (King's Cup), Blaugrana (Blue + Carmine 'Barcelona Club'), 
Remontada (comeback/recovery), Calcio (football/ soccer), Libro (sweeper), Tifo (display of flags, pictures by fans), Ultras (ultra-fanatical fans), Tiki Taka (football short passes, control and position), Pichichi (top goal scorer), Futsal (a form of five-player team football), vuvuzela (a musical instrument played by fans), Ballon d'Or (Golden Ball), and FIFA (Federation Internationale de Football Association).

\subsection{Eponymy}

Is a linguistic procedure in which a word is derived from a person, an object, a place, a race ... etc. Burton and Humphries (1992, p. 78) explain how eponyms are made "By derivation from proper names, either in English or in foreign languages. For example, academy comes from the Greek name for the garden near Athens in which Plato taught; boycott comes from the name of a certain Captain Boycott, an Irish landlord who was ostracized by his neigbours in $1880 "$ ".

Eponyms in football as Cruyff turn $\rightarrow$ (Dutchman Johan Cruyff), Bosman ruling $\rightarrow$ (Belgian Jean-Marc Bosman), Jules Rimet Trophy/Cup $\rightarrow$ (French Jules Rimet), Fergie time $\rightarrow$ (Sir Alex Ferguson), Mexican waves $\rightarrow$ (Mexico), Cuauhtemina $\rightarrow$ (Mexican Cuauhtemoc Blanco).

\subsection{Backformation}

Backformation is a morphological process for generating a new word out of an already existing one by clipping off affixes as resurrection $\rightarrow$ resurrect. This process is commonly employed to create words from borrowed Latin, Greek, and French words. Lieber (2009, p. 52) states "There are words that historically existed as monomorphemic bases, but which ended in a sequence of sounds identical to or reminiscent of that certain affixes. When native speakers come to perceive these words as being complex rather than simple, they create what is called a backformation". Common examples of backformation as peddle $\rightarrow$ peddler, burgle $\rightarrow$ burglar, and surveil $\rightarrow$ surveillance; on the other hand, backformation in English football language include: edit $\rightarrow$ editor, televise $\rightarrow$ television, and liaise $\rightarrow$ liaison.

\section{Conclusion}

Almost all English morphological characteristics are represented in English football language. After thorough and comprehensive investigation into studies, syllabuses, libraries and bookshops, the researcher has failed to find materials in English football linguistics. The researcher recommends that football language study should be introduced at English departments. Collection, formulation and design of English football language curriculums/syllabuses on linguistics and English for specific purposes (ESP). Generalization of this study to include further studies and researches on other English football linguistic characteristics as semantic and syntactic features. Further focus and studies should also be directed characteristics of other sports' branches linguistically as basketball, volleyball, tennis ... etc.

\section{References}

Burton, S., \& Humphries, J. (1992). Mastering English Language (2nd ed.). Palgrave.

Finegan, E. (2015). Language: It's Structure and Use (7th ed.). Cengage Learning. Stamford, USA.

Franklin, V., Rodman, R., \& Hyams, N. (2011). An Introduction to Language. Wadsworth-Cengage Learning.

Hazem. A., \& Kanaan, M. (2020). Domain Adverbs in Legal English Texts: Problems and Strategies. IUP Journal of English Studies, 15(4), 130-141.

Hurtford, J., Heasley, B., \& Smith, M. (2007). Semantics-A Coursebook (2nd ed.). Cambridge University Press. https://doi.org/10.1017/CBO9780511841668

Kamil, D. F., \& Hazem, A. H. (2019). A Syntactic O-Semantic Study of Negative Particles in Arabic Literary Discourse with Reference to Translation. Arab Journal for Arts and Human Studies, 3(10), 327-341. Htt://dx.doi.org/10.33850/ajahs.v.3n.10 p.327

Lieber, R. (2009). Cambridge Introductions to Language and Linguistics-Introducing Morphology. Cambridge University Press.

Nation, I., (2013). Learning Vocabulary in Another Language (2nd ed.). Cambridge University Press. https://doi.org/10.1017/CBO9781139858656

O’Grady, W., Dobrovolsky, M., \& Katamba, F. (1997). Contemporary Linguistics: An Introduction. Addison Wesley-Longman Limited.

Parker, F., \& Riley, K. (2010). Linguistics for Non-Linguists (5th ed.). Pearson.

Sambrook, G. A. (1947). The English Language. Longmans, Green \& Co. London. UK. 
Saraceni, M. (2015). World Englishes: A Critical Analysis. Journal of English as a Lingua Franca.

Stageberg, N. (1981). An Introductory English Grammar (4th ed.). Holt, Rinehart and Winston, Inc.

Widdowson, H. (1996). Oxford Introductions to Language Study—Linguistics. Oxford University Press.

Yule, G. (1996). The Study of Language (2nd ed.). Cambridge University Press.

Yule, G. (2010). The Study of Language (4th ed.). Cambridge University Press.

\section{Copyrights}

Copyright for this article is retained by the author, with first publication rights granted to the journal.

This is an open-access article distributed under the terms and conditions of the Creative Commons Attribution license (http://creativecommons.org/licenses/by/4.0/). 